\title{
PENGEMBANGAN ENSIKLOPEDI BIOLOGI MOBILE BERBASIS ANDROID MATERI POKOK PTERIDOPHYTA DALAM RANGKA IMPLEMENTASI KURIKULUM 2013
}

\author{
Dian Noviar \\ Fakultas Sains dan Teknologi Universitas Islam Negeri Sunan Kalijaga \\ email: diannoviar84@yahoo.co.id
}

\begin{abstract}
Abstrak: Penelitian bertujuan untuk menghasilkan Ensiklopedi Biologi Mobile berbasis Android untuk siswa Madrasah Aliyah dan mengetahui kelayakan produk yang dihasilkan. Model pengembangan menggunakan model ADDIE. Empat tahapan pada prosedur pengembangan ADDIE yang dilalui dalam penelitian ini adalah Analysis, Design, Develop, dan Evaluation. Produk dinilai oleh 3 orang pakar media, materi, dan IT, serta 9 orang peer reviewer, dan 3 orang guru Biologi. Uji coba terbatas dilakukan pada 25 orang siswa kelas X di MA Ali Maksum Yogyakarta dan didukung 5 orang mahasiswa pendidikan biologi untuk mengetahui tanggapan responden terhadap produk ensiklopedi biologi mobile. Instrumen yang digunakan berupa angket check list. Data yang berupa data kualitatif yang diubah kuantitatif kemudian ditabulasi dan dianalisis secara deskriptif kuantitatif dan kualitatif untuk mengetahui kualitas produk yang dikembangkan. Hasil penelitian menunjukkan bahwa produk yang telah dikembangkan berdasarkan penilaian keseluruhan reviewer memperoleh kualitas Sangat Baik $(87,42 \%)$. Hasil uji coba terbatas dari respon siswa dan mahasiswa menunjukkan bahwa produk tersebut juga memiliki kualitas Sangat Baik $(89,3 \%$ dan $84,8 \%)$.
\end{abstract}

Kata Kunci: ensiklopedi biologi, android, mobile, Kurikulum 2013

\section{DEVELOPINGANDROID-BASED MOBILE BIOLOGY ENCYCLOPEDIA OF THE CORE MATERIAL OF PTERIDOPHYTA FOR IMPLEMENTING CURRICULUM 2013}

\begin{abstract}
The objective of the study is to develop anandroid-basedmobile biology encyclopedia for students of Madrasah Aliyah as well as to examine the feasibility of the product. This research belongs to Research and Development (R \& D) design using ADDIE (Analysis, Design, Development, Implementation, and Evaluation) model.The quality of the product was assessed by three experts (on media, material, and IT), nine peer reviewers, and three biology teachers.Limited trial was carried out to the 25 students of class X at MA Ali Maksum Yogyakarta and fivebiology undergraduate students in order to reveal their responses towards the product. Their responses were recorded in a check list questionnaire. Such qualitative data which were translated into quantitative forms were then analyzed using qualitative and quantitative methods. The reviewers' responses show thatthe quality of the product is Very Good $(87.42 \%)$. Responses of high school and under graduate students confirm that the product is Very Good (89.3\% and $84.8 \%)$.
\end{abstract}

Keywords: Biology Encyclopedia, Android, Mobile, Curriculum 2013

\section{PENDAHULUAN}

Indonesia merupakan negara yang memiliki keanekaragaman hayati yang sangat tinggi baik pada kelompok flora maupun kelompok fauna sehingga Indonesia dijuluki sebagai negara "megabiodiversitas". Indonesia menduduki peringkat ke-3 setelah Brazil dan Zaire. Indonesia memunyai ribuan spesies dari kelompok flora baik flora tingkat rendah maupun flora tingkat tinggi. Flora yang berupa tumbuhan merupakan kingdom yang memiliki keanekaragaman sangat tinggi sehingga selalu memberikan ruang untuk terus menerus dikaji. Pada tingkat spesies keanekaragaman tersebut meliputi berbagai hal antara lain struktur morfologi, anatomi maupun genetiknya.

Tema tentang keanekaragam tumbuhan serta seruan untuk melakukan pengamatan de- 
ngan detil terdapat dalam QS. Asy-Syu'araa'(26): 7. Ayat ke-7 ini mengisyaratkan juga bahwa keanekaragaman tumbuhan yang selalu berkembang biak karena memiliki alat reproduksi memiliki manfaat, baik yang sudah maupun belum diketahui (Shihab, 2011:187). Manusia bisa memanfaatkan makhluk ciptaan Tuhan ini, manusia sebagai makhluk yang berakal dan menjadi kholifah di muka bumi memunyai tugas untuk menggali dan mengkaji potensi yang ada pada penciptaan flora sehingga mampu bertadabbur akan tanda-tanda kebesaran Tuhan dan mampu menjaga dan melestarikan alam.

Kebanyakan manusia hanya mampu memanfaatkan kekayaan hayati yang ada tanpa memikirkan keberadaan dan kelestarian ekosistem yang ada, sehingga semakin lama alam ini semakin rusak dan jumlah keanekaragaman hayati semakin menurun dari tahun ke tahun. Seperti yang tertera dalam Alquran Qs. Arrum: 41 bahwa telah nampak kerusakan di darat dan di laut karena perbuatan tangan manusia, supaya Allahswt merasakan kepada mereka sebagian dari akibat perbuatan mereka, supaya mereka kembali (ke jalan yang benar). Oleh sebab itu, perlu adanya upaya untuk melestarikan keanekaragaman hayati yang ada di alam, terutama di Indonesia dimana kita berpijak. Masih banyak spesies yang belum kita kenal, belum teridenfikasi, terinventarisasi bahkan banyak spesies yang telah terancam punah akibat ulah manusia. Adapun upaya awal yang dapat dilakukan adalah inventarisasi, identifikasi dan konservasi spesies yang ada.

Keanekaragaman hayati menjadi salah satu bahan kajian biologi yang sangat penting dipahami oleh siswa baik teori maupun praktiknya dalam kehidupan sehari-hari. Hal tersebut perlu diketahui siswa terkait keberadaan keanekaragaman hayati di Indonesiaterancam punah yang disebabkan oleh aktivitas manusia sehingga keseimbangan lingkungan terganggu. Kepunahan tersebut dapat disebabkan oleh adanya global warming, kerusakan lingkungan akibat kebakaran hutan, banjir, tanah longsor, pencemaran lingkungan, dan masih banyak kasus-kasus lainnya. Oleh sebab itu, perlunya peran pendidikan untuk meningkatkan kualitas pemahaman siswa secara kontekstual tentang keanekaragaman hayati melaluiimplementasiKurikulum 2013yang dilaksanakan mulai tahun ini.

Katuuk (2014:13-26) mengemukakan bahwa dalam implementasi Kurikulum 2013 perlu manajemen yang baik sehingga mencapai kualitas yang diharapkan. Guru dan kepala sekolah berperan penting sebagai aktor utama dalam implementasi kurikulum tersebut. Pada dasarnya tujuan dirombaknya kurikulum tingkat satuan pendidikan (KTSP) menjadi Kurikulum 2013 sebenarnya cukup baik, yaitu untuk membangkitkan kemampuan nalar dan kreativitas anak didik secara merata. Pasalnya selama ini kurikulum yang mampu memacu hal tersebut hanya dapat diperoleh di sekolah-sekolah tertentu saja. Hal ini menjadi alasan mengapa peringkat pendidikan Indonesia jauh tertinggal jika dibandingkan dengan negara lain seperti Finlandia, Kanada, dan Australia. Bahkan kualitas pendidikan kita masih di bawah negara-negara tetangga, seperti Singapura, Brunei Darussalam, dan Malaysia.

Tantangan besar untuk proses pendidikan ideal adalah tidak hanya mempersiapkan generasi bangsa yang mampu hidup hari ini, tetapi generasi yang dibekali dengan kemampuan hidup di masa depan. Tantangan di era global semakin kompleks dan membutuhkan penyelesaian masalah dengan pola pikir kritis dan penuh kreativitas. Subali dan Mariyam (2013:365-381) menyatakan bahwa pengembangan kreativitas dalam keterampilan proses sains bagi siswa penting. Kreativitas yang diiringi oleh nilai-nilai lokal menjadikan jati diri siswa yang mantap dan mampu beradaptasi dalam setiap kejadian dan interaksi di lingkungannya. Mata pelajaran biologi merupakan bahan kajian sains yang memahami lingkungan alam sekitarnya dengan tidak melupakan etika dalam memperlakukan lingkungan dengan baik. Oleh sebab itu, konten biologi tentang keanekaragaman hayati perlu dipahami secara holistik oleh setiap siswa sehingga kontekstualitas pemaknaan siswa dapat memberikan dampak positif dalam mengatasi permasalahan lingkungan sosial, alam, dan masyarakat secara luas. Munculnya berbagai kreasi dan inovasi siswa yang tetap mempertahankan keaslian lingkungan sekitarnya dan tuntunan agama, manifestasi dari pemaknaan konten biologi tentang keanekaragaman hayati.

Proses pembelajaran biologi yang berlangsung di Madrasah Aliyah pada umumnya masih berorientasi pada hasil (learning outcome). Hal tersebut selaras dengan hasil observasi dan wawancara yang dilakukan di MA Ali Maksum bahwa guru belum memanfaatkan sumber belajar biologi berbasis Information and Technology. Surjono dan Gafur (2010:161-175) mengemu- 
kakan bahwa belum semua SDM antusias, termotivasi (lebih-lebih tenaga guru senior), dan memiliki kompetensi sesuai yang diharapkanuntuk mengimplimentasikan ICT dalam rangka peningkatan mutu pembelajaran. Selain itu, Nilakusmawati (2010:147-160) menunjukkan bahwa para guru yang mengikuti pelatihan sebesar $67,5 \%$ tidak mengetahui apa itu internet dan $72,5 \%$ tidak pernah memanfaatkan fasilitas yang ada di internet. Guru lebih mengedepankan pada penguasaan materi biologi yang telah ditargetkan, siswa cenderung pasif di kelas, aspek sikap dan proses kurang optimal.

Pembelajaran sistem ini mengakibatkan kemampuan dan kreativitas berpikir siswa kurang berkembang serta materi yang telah diajarkan hanya terekam siswa pada memori jangka pendek karena pembelajaran masih dominan dengan pola hafalan konsep-konsep biologi. Meskipun demikian, secara fasilitas para siswa sudah memiliki smartphone, laptop, notebook untuk digunakan dalam proses pembelajaran biologi, tetapi dari segi pemanfaatan belum maksimal. Contohnya, siswa diberikan kesempatan menggunakan laptop dan notebook untuk akses internet, selain itu penggunaan smartphone lebih banyak digunakan sosial media.Ditambah lagi hasil belajar yang dicapai siswa kurang optimal. Kegiatan belajar mengajar akan lebih bermakna jika siswa terlibat aktif dalam pembelajaran dengan didukung guru yang kreatif, sumber belajar yang memadai dan dapat mengakomodir kemampuan siswa.Lebih jauh diharapkan dengan pembelajaran yang memadai (adequate) akan menumbuhkan kreativitas dan kemampuan berfikir kritis yang semuanya akan sangat bermanfaat bagi aktualisasi dan kesiapan anak menjadi generasi berkualitas untuk menghadapi perannya yang lebih luas dan kompleks pada masa akan datang.

Hal tersebut sejalan dengan perkembangan dunia informasi dan teknologi khususnya dalam bidang pendidikan. Selama ini perkembangan siswa dalam belajar biologi sudah memanfaatkan banyak sumber informasi. Contohnya adalah internet yang dapat diakses melalui handphone, tablet, laptop, komputer yang terhubung dengan jaringan internet. Keberadaan hardware dan software tersebut dapat dimanfaatkan untuk belajar siswa tentang keanekaragaman hayati. Salah satunya tentang kunci determinasi tumbuhan berbasis mobile android yang termasuk dalam ensiklopedi mobile. Rizki dkk (2014:1-12) menegaskan bah- wa sekarang ini teknologi telah berkembang pesat khususnya handphone. Perkembangan handphone berupa smartphone android yang dapat membantu masyarakat dalam memperoleh informasi yang bermanfaat. Hasil penelitian ini mengembangkan sebuah aplikasi ensiklopedia android tentang kebudayaan kota palembang. Salah satu metode pengembangan sistem yang digunakan yaitu, metodemobile-D yang terdiri dari lima tahapan yakni explore, initialize, productionize, stabilize, system test and fix.

\section{METODE}

Jenis penelitian ini merupakan penelitian pengembangan dengan model ADDIE. Metode penelitian iniadalah metode penelitian yang digunakan untuk menghasilkan produk tertentu dan menguji keefektifan produk tersebut. Produk yang dihasilkan adalah berupa sumber belajar Ensiklopedi untuk siswa kelas X. Langkah-langkah penelitian dan pengembangan adalah potensi dan masalah, pengumpulan data, desain produk, validasi desain, revisi desain, uji coba produk, revisi produk, uji coba pemakaian, revisi produk, dan produksi masal (Sugiyono, 2011:409).

Adapun porsedur penelitian ini menerapkan model ADDIE (Analysis, Design, Development, Implementation, and Evaluation). Langkah-langkah prosedur ADDIE sebagai berikut: a) Tahap analisis (Analysis) meliputi: analisis kompetensi, analisis materi, analisis karakteristik siswa, dan analisis intruksional. b) Tahap perencanaan (Design) meliputi: penyusunan kerangka struktur (outline), penentuan sistematika, dan perancangan alat evaluasi. c) Tahap pengembangan dan produksi (Development and Production) meliputi: pra penulisan, penulisan draf, penyuntingan, revisi, uji coba terbatas. d) Tahap implementasi (Implementation) dilakukan dengan ujicoba secara luas/empirik untuk memperoleh masukan dari pihak-pihak yang berkepentingan seperti guru dan siswa. e) Tahap evaluasi (Evaluation) dilakukan untuk mengetahui keefektifan dalam mencapai tujuan atau kompetensi yang telah ditentukan (Padmo dkk, 2004:415-421).

Instrumen yang digunakan untuk mengukur kualitas produk ensiklopedi yangberupa lembar angket dengan kriteria instrumen antara lain: aspek penyajian materi biologi, kurikulum, evaluasi belajar, keterlaksanaan, kualitas tampilan, kebahasaan, rekayasa perangkat lunak,Interface, Reusable, Maintainable, Compatibility. Selain itu, 
kriteria instrumen untuk siswa antara lain:minat terhadap media, penguasaan materi, tampilan, dan keterlaksanaan. Penilaian produk terdiri dari para ahli/reviewer, peer reviewer, guru, respon siswa dan mahasiswa. Data angket dianalisis menggunakan statistik deskriptif dengan cara menghitung rerata skor yang diperoleh dan persentase hasil sesuai kategori penilaian ideal. Analisis skor yang digunakan adalah analisis deskriptif kualitatif dan kuantitatif (Sudjana, 2010:109).

\section{HASIL DAN PEMBAHASAN}

Penelitian ini menghasilkan produk $E n-$ siklopedi Biologi Mobile yang diberi nama Ensiklopedi Mobile Pteridophyta menjadi salah satu alternatif baru dalam dunia pendidikan. Pengembangan produk tersebut diharapkan memberikan banyak kontribusi dalam meningkatkan kualitas pendidikan. Produk ensiklopedi mobile berbasis android, memiliki nuansa yang berbeda karena penggunaannya portable, adanya proses IT didalamnya, koneksi dengan internet sehingga para pengguna terutama para siswa dapat memanfaatkan handphone untuk kegiatan pembelajaran biologi. Untuk kemudahan dalam mengakses perlu pengubahan nama yang dimaksudkan agar mudah ditemukan oleh mesin pencarian Google dan memberi gambaran materi spesifik pada aplikasi.

Hasil dari pengembangan sumber belajar ensiklopedi mobile dikemas dalam bentuk master aplikasi yang memiliki extensi file *.APK (aplication pakage) yang dirancang khusus untuk dijalankan pada handphone. Master aplikasi selanjutnya digunakan untuk proses instalaplikasi pada handphone. Aplikasi Ensiklopedi Mobile terdiri dari beberapa sub menu materi yang di antaranya adalah: menu "Materi", "Identifikasi", "Evaluasi", "Diskusi", "Info", dan "Kurikulum". Masing-masing menu memiliki fungsi tersendiri untuk memberi kemudahan siswa mempelajari materi.

Menu materi memuat jabaran materi Pteridophyta yang terdiri atas pengenalan peridophyta, ciri-ciri peridophyta, reproduksi, klasifikasi, dan family pteridophyta. Menu identifikasi berfungsi untuk melacak kedudukan taksonomi tumbuhan paku yang ditemui siswa di lingkungan alam. Dengan menggunakan menu identifikasi siswa diharapkan dapat lebih mudah melakukan observasi tumbuhan Pteridophyta yang ada di lingkunganya. Dengan bantuan gambar dan teks deskripsi morfologi yang memadai, membantu siswa melakukan proses pengklasifikasian, pengukuran, dan penyimpulan objek yang diamati. Menu diskusi berfungsi untuk memfasilitasi siswa berdiskusi melalui dunia maya. Siswa bisa secara aktif bertanya atau memberi tanggapan di dalam menu ini. Menu info berfungsi untuk memberi update-an informasi seputar perkembangan aplikasi. Menu bantuan, yaitu menu yang berisi panduan singkat pengoperasian aplikasi media pembelajaran ini pada siswa.

Menu yang terakhir adalah menu kurikulum yang berisi jabaran Kompetensi Inti dan Kompetensi Dasar yang harus dikuasai siswa. Aplikasi Ensiklopedi Mobile Pteridophyta dapat diakses kapanpun dan dimanapun sehingga dengan aplikasi siswa dapat belajar mandiri. Menu materi, identifikasi, evaluasi berjalan pada mode offline sehingga dapat berjalan tanpa harus tergantung koneksi jaringan internet, sedangkan forum dan info berjalan pada mode online sehingga siswa dapat berdiskusi dimanapun selama masih ada jaringan internet.Hasil pengembangan Ensiklopedi Mobile Pteridophyta menggunakan model ADDIE sebagai berikut.

\section{Tahap Analisis}

Tahap ini dimulai dengan analisis kebutuhan. Analisis kebutuhan merupakan suatu kegitan ilmiah yang melibatkan berbagai teknik pengumpulan data dari berbagai sumber informasi untuk mengetahui kesenjangan (gap) antara keadaan yang seharusnya terjadi (ideal) dengan keadaan sebenarnya terjadi (reality). Apabila kesenjangan tersebut dianggap sebagai suatu masalah yang memerlukan pemecahan, kesenjangan tersebut dianggap sebagai suatu kebutuhan (needs) (Warsita, 2008:221). Pada tahap ini didapatkan informasi dari berbagai jurnal bahwa electronic learning memiliki keterbatasan dari segi fleksibilitas dan portabilitas perangkat yang digunakan.Perangkat yang biasa digunakan pada electronic learning antara lain adalah TV, VCD/DVD, digital proyektor, atau Personal Computer (PC). Penggunaan peralatan tersebut mengharuskan penggunanya berada di tempat tertentu.

Sementara itu, pesatnya perkembangan teknologi mobile khususnya handphone membuka peluang untuk mengatasi keterbatasan electronic learning. Hal ini didukung oleh beberapa faktor yaitu: (1) jumlah handphone banyak, murah dan canggih serta kenyataan bahwa pengguna hand- 
phone lebih banyak dari pengguna komputer; (2) perkembangan teknologi jaringan seluler yang semakin pesat $(2 \mathrm{G}, 3 \mathrm{G}, 4 \mathrm{G})$ sehingga memungkinkan jangkauan konektifitas yang lebih luas; (3) portabilitas perangkat mobile yang tinggi (Riyanto dan Tamimuddin dkk, 2006:386). Dengan semua faktor pendukung yang dimiliki, handphone berpotensidikembangkan menjadi sumber belajar yang murah dan efisien tetapi memiliki kemampuan yang tinggi untuk menyampaikan materi biologi.

Penyusunan materi pengembangan mempertimbangkan perkembangan kognitif siswa. Siswa kelas X Madrasah Aliyah yang rata-rata memiliki usia 17 tahun. Menurut teori Piaget, perkembangan kognitif siswa pada tahap ini berada pada operasional formal. Pada tahap ini siswa telah memiliki kemampuan untuk mengkoordinasikan dua ragam kemampuan kognitif, yakni kapasitas menggunakan hipotesis dan kapasitas menggunakan prinsip-prinsip abstrak. Dengan potensi tersebut siswa memiliki kemampuan untuk memecahkan masalah menggunakan anggapan dasar yang relevan dengan lingkungannya (Syah, 2008:29-33). Dengan kemampuan berpikir operasional formal dapat dijadikan landasan untuk mengembangkan media pembelajaran yang memuat aspek-aspek fisiologis materi biologi yang tidak bisa diamati secara langsung.

Pada analisis kurikulum pengembang dianalisis berbagai karakteristik Standar Kompetensi dan Kompetensi Dasar materi pelajaran biologi Madrasah Aliah. Hal ini mengingat bahwa tidak semua materi cocok untuk dibawakan dengan konsep mobile yang di antaranya adalah materi bersifat "hands on", keterampilan sebagai mana dokter gigi, seni musik khususnya mencipta lagu, interview skills, team work seperti marketing maupun materi yang membutuhkan pengungkapan ekspresi seperti tarian (Wijaya, 2006:1-2).

Tumbuhan paku (Pteridophyta) merupakan salah satu bagian dari keanekaragaman hayati dan sebagai bahan kajian biologi yang sangat penting bagi siswa, karena materi tersebut menyentuh berbagai aspek yang sering dijumpai siswa dalam kehidupan sehari-hari. Bilamana keberlangsungan keanekaragaman hayati terancam keberadaannya yang disebabkan oleh dampak aktivitas manusia yang menjadikan keseimbangan lingkungan terganggu, maka keanekaragaman hayati baik flora dan fauna akan terancam punah. Di dalam kurikulum SMA/MA materi ini tertuang pada
KD 3.9, yaitu mendeskripsikan ciri-ciri divisio dalam dunia tumbuhan dan perannya bagi kelangsungan hidup di bumi.Selain itu juga tertuang padaKD 4.11, melakukan pengamatan berbagai jenis tumbuhan yang ada di lingkungan sekitar dan mengelompokkan menurut ciri divisionya serta menyusun laporan. Jika di cermati, target kemampuan yang dimiliki oleh siswa selain mampu memahami materi pada level kognitif, siswa juga dituntut untuk mampu menggunakan keterampilan proses dalam biologi. Keterampilan proses terdiri dari pengamatan, pengklasifikasian, pengukuran, penyimpulan, pengomunikasian, dan peramalan. Oleh sebab itu, produk ensiklopedi mobile yang dikembangkan selain memuat materi juga perlu dilengkapi dengan menu tambahan yang mampu mengakomodasi keterampilan proses dalam biologi. Salah satunya dengan menyajikan menu identifikasi tumbuhan di dalam aplikasi tersebut.

Pada tahap analisis pengguna mobile dan mobile devicedilakukan untuk mengetahui jenis sistem operasi dan spesifikasi handphone dilapangan. Dari www.pulsaonline.com diketahui bahwa handphone di lapangan memiliki berbagai variasi baik dari segi hardware maupun software. Setelah dilakukan analisa mengenai berbagai variasi tersebut diketahui bahwa sistem operasi pada handphone sangat memengaruhi tahap pengembangan aplikasi selanjutnya.

Berdasarkan data angket bahwa persentase basis sistem operasi handphone yang dimiliki siswa antara lain: Java, Java Cina, Blackberry, dan Android. Java dan Java Cina memperoleh persentase sebesar $41,17 \%$ dan 20,58\%. Meskipun memperoleh persentase yang cukup besar, berbagai keterbatasan yang dimiliki oleh Java maupun Java Cina dari segi ukuran memori internal, kecepatan prosesor dan resolusi layar menyebabkan handphone Java dan Java Cina kurang mendukung untuk dikembangkan sebagai Media Mobile. Demikian juga dengan handphone Black Berry, meskipun telah memiliki sumber daya hardware yang tinggi, jumlah pengguna yang hanya $11,76 \%$ menyebabkan pengembangan Media Mobile pada sistem operasi ini kurang efektif.

Handphone dengan sistem operasi Android menempati peringkat ke-2, yaitu sebesar 26,47\%. Meskipun dari segi jumlah pengguna hanya sebesar $26,47 \%$, handphone jenis ini telah memiliki ukuran memori, kemampuan komputasi (pemrosesan), dan konektifitas melebihi handphone biasa. 
Dari waktu ke waktu jumlah pengguna handphone jenis ini mengalami peningkatan yang signifikan. Data penjualan handphone Android di Indonesia periode Januari 2015 yang diperoleh dari http:// gs.statcounter.com mencapai 59,78\% dari keseluruhan jenis handphone. Sumberdaya yang tinggi dan persentase pengguna yang cukup banyak menjadikan pengembangan produk Ensiklopedi Mobile Pteridophyta pada handphone Android lebih efektif.

\section{Tahap Perancangan}

Tahap design merupakan tahap perancangan prototype Ensiklopedi Mobile. Pada tahap ini dilakukan perancangan arsitektural (flow chart), interface (antar muka), kerangka materi, urutan materi, alat evaluasi, dan fitur tambahan. Perancangan produk Ensiklopedi Mobile Pteridophyta merujuk pada kriteria desain yang dikembangkan oleh Quesinberry (2011:1-2), perancangan layout yang disesuaikan untuk layar yang memiliki ukuran kecil, materi disusun secara singkat dan sesederhana, pengoperasian mudah dilakukan dengan satu tangan, desain penuh warna namun tetap sederhana, penggunaan yang relevan dengan kebutuhan, dan konten materi maupun sistem fleksible untuk diperbaharui secara berkesinambungan.

\section{Tahap Pengembangan}

Pada tahap ini dilakukan penilaian prototype produk oleh reviewer dan peer reviewer. Hal ini dikarenakan Ensiklopedi Mobile harus memiliki kualitas yang baik. Kualitas diartikan sebagai kesesuaian dengan standar tertentu, kesesuaian dengan kebutuhan tertentu, kesepadanan dengan karakteristik dan kondisi tertentu, keselarasan dengan tuntutan zaman, ketersediaan pada saat yang diperlukan, keterandalan dalam berbagai kondisi, daya tarik yang tinggi dan sebagainya (Warsita, 2008:258). Hasil penilaian seluruh reviewer dan peer reviewer disajikan pada Tabel 1.

Aspek compatibility memperoleh skor tertinggi, yaitu $100 \%$. Compatibility merupakan aspek yang mengukur tingkat kecocokan aplikasi terhadap berbagai jenis handphone di lapangan. Perolehan skor maksimal mengindikasikan bahwa aplikasi dapat berjalan pada semua handphone Android di lapangan. Selama proses pengembangan peneliti juga telah melakukan simulasi compatibility dengan cara menginstal aplikasi pada berbagai jenis handphone Android dengan variasi meliputi: merek, ukuran layar, ukuran memory interneal, kecepatan prosesor, dan versi sistem operasi. Gandhewar dan Sheikh (2010:1-17) membandingkan sistem operasi Android dengan Simbian dan Windows Mobile dengan kriteria tertentu diantaranya adalah : Portabylity, Reliability, Connectivity, Open Platform, Kernel Size, Standard, dan Special Featur. secara keseluruhan

Tabel 1. Kualitas Ensiklopedi Mobile Hasil Penilaian Ahli Media, Ahli Materi, Ahli IT, Peer Reviewer, dan Guru Biologi

\begin{tabular}{clcccc}
\hline No. & \multicolumn{1}{c}{ Aspek } & Indikator/ Kriteria & Skor Rata-rata & $\begin{array}{c}\text { Persentase } \\
\text { Ideal }\end{array}$ & Kualitas \\
\hline 1. & Kualitas Tampilan & $1,2,3,4,5,6,7,8$ & 35,37 & $88,48 \%$ & $\mathrm{SB}$ \\
2. & Rekayasa perangkat lunak & $9,10,11$ & 13,82 & $92,16 \%$ & $\mathrm{SB}$ \\
3. & Kurikulum & 12,13 & 8,60 & $86 \%$ & $\mathrm{SB}$ \\
4. & Penyajian materi & $14,15,16,17,18$ & 21,3 & $85,23 \%$ & $\mathrm{SB}$ \\
5. & Keterlaksanaan & 19,20 & 9,2 & $92 \%$ & $\mathrm{SB}$ \\
6. & Evaluasi & 21,22 & 8,5 & $85 \%$ & $\mathrm{SB}$ \\
7. & Kebahasaan & $23,24,25,26$ & 16,91 & $84,58 \%$ & $\mathrm{SB}$ \\
8. & Interface & $27,28,29,30,31$, & 24,00 & $80 \%$ & $\mathrm{~B}$ \\
9. & Reusable & 32, & 4,00 & $80 \%$ & $\mathrm{~B}$ \\
10. & Maintainable & 33 & 9 & $90 \%$ & $\mathrm{SB}$ \\
11. & Compatibility & 34,35 & 10 & $100 \%$ & $\mathrm{SB}$ \\
\hline \multicolumn{7}{r}{ Total } & Total Persentase Ideal & 37,37 & $\mathbf{1 6 0 , 7 3}$ & \\
\hline
\end{tabular}


Tabel 2. Kualitas EnsiklopediMobile Hasil Tanggapan 5 Orang Mahasiswa

\begin{tabular}{|c|c|c|c|c|c|}
\hline Aspek & $\begin{array}{c}\text { Indikator/ } \\
\text { Kriteria }\end{array}$ & $\begin{array}{l}\text { Skor } \\
\text { Max }\end{array}$ & $\begin{array}{c}\text { Skor } \\
\text { Rata-rata }\end{array}$ & $\begin{array}{l}\text { Persentase } \\
\text { Ideal }\end{array}$ & Kualitas \\
\hline 1. Minat Terhadap Media & $1,2,3,4$ & 20 & 17,2 & $86 \%$ & SB \\
\hline 2. Penguasaan Materi & $5,6,7,8$ & 20 & 18,2 & $91 \%$ & SB \\
\hline 3. Tampilan & $9,10,11,12$ & 20 & 17,6 & $88 \%$ & SB \\
\hline 4. Keterlaksanaan & $13,14,15$ & 15 & 14 & $93,3 \%$ & SB \\
\hline Total & 15 & 75 & 67 & & \\
\hline Total Persentase Ideal & & & & $89,3 \%$ & $\begin{array}{l}\text { Sangat } \\
\text { Baik }\end{array}$ \\
\hline
\end{tabular}

Tabel 3. Kualitas EnsiklopediMobile Hasil Tanggapan 25 Orang Siswa

\begin{tabular}{|c|c|c|c|c|c|}
\hline Aspek & $\begin{array}{c}\text { Indikator/ } \\
\text { Kriteria }\end{array}$ & $\begin{array}{l}\text { Skor } \\
\text { Max }\end{array}$ & $\begin{array}{c}\text { Skor } \\
\text { Rata-rata }\end{array}$ & $\begin{array}{l}\text { Persentase } \\
\text { Ideal }\end{array}$ & Kualitas \\
\hline 1. Minat terhadap Media & $1,2,3,4$ & 20 & 16,8 & $84 \%$ & SB \\
\hline 2. Penguasaan Materi & $5,6,7,8$ & 20 & 16,8 & $84 \%$ & SB \\
\hline 3. Tampilan & $9,10,11,12$ & 20 & 17 & $85 \%$ & SB \\
\hline 4. Keterlaksanaan & $13,14,15$ & 15 & 13,1 & $87,3 \%$ & SB \\
\hline Total & 15 & 75 & 63,7 & $84,8 \%$ & \\
\hline Total Persentase Ideal & & & & & angat Baik \\
\hline
\end{tabular}

Android mendapatkan skor yang lebih tinggi dibanding sistem operasi Symbian dan Windows Mobile. Hal ini menunjukkan bahwa android merupakan sistem operasi yang cukup handal. Android diramalkan akan menjadi pemimpin baru dalam sistem operasi Mobile.

Hasil pengujian menunjukkan aplikasi bisa berjalan dengan lancar pada Samsung Galaxy Young, Samsung Galaxy S2, Axio Pico 4, Lenovo A568, Motorola Atrik, Tablet Asus Fonepad A375. Berbagai handphone yang dicoba memiliki variasi ukuran layar mulai dari 3,2 inch sampai dengan 7 inch; Ukuran memory internal antara $160 \mathrm{MB}$ sampai dengan $8000 \mathrm{MB}$; Kecepatan prosesor antara $800 \mathrm{MHz}$ sampai dengan Quard Core 1,2 GHz; Virsi Android Gingerbread sampai dengan Kit Kat. Variasi spesifikasi handphone ujicoba sudah cukup mewakili variasi handphone yang ada di lapangan, sehingga aplikasi compatible dengan semua handphone Android.

Hasil penilaian dan saran dari reviewer digunakan sebagai dasar perbaikan produk ensiklopedi mobile. Setelah dilakukan perbaikan aplikasi Ensiklopedi Mobile diuji cobakan secara terbatas pada lima mahasiswa prodi Pendidikan Biologi. Ujicoba dilakukan untuk melihat tanggapan mahasiswa sebagai penggunaaplikasi Ensiklopedi Mobile. Adapun hasil tanggapan mahasiswa terhadap Ensiklopedi Mobile dapat dilihat pada Tabel 2.

Tanggapan Mahasiswa terhadap kualitas Ensiklopedi Mobile termasuk dalam kategori Sangat Baik (SB). Tahap selanjutnya setelah ujicoba terbatas yang dilakukan pada 25 Siswa kelas X MA Ali Maksum Yogyakarta. Adapun hasil dari ujicoba terbatas disajikan pada Tabel 3

Berdasarkan Tabel 3 dapat kita lihat, aspek keterlaksanaan memperoleh persentase tertinggi baik dari hasil uji coba terbatas. Hal ini mengindikasikan bahwa Ensiklopedi Mobile dapat dapat digunakan kapan saja dan dimana saja. Keterlaksanaan penggunaan ini berkaitan erat dengan perangkat yang digunakan yaitu handphone. Salah satu kelebihan handphone dibanding perangkat elektronik lain seperti laptop dan Personal Computer $(P C)$ adalah kemampuan flexybilitas dan portabilitasnya yang tinggi. Dengan memanfaatkan handphone sebagai perangkat pembelajaran akan memudahkan siswa belajar tanpa harus terikat waktu dan tempat.

Berdasarkan hasil keseluruhan, Ensiklopedi Mobile telah memenuhi kriteria sebagai sumber belajar yang baik. Ensiklopedi memberikan penjelasan secara lebih detail dan mendalam dari kata yang dimaksud. Ensiklopedi merupakan kumpulan tulisan yang berisi tentang penjelasan berbagai 
macam informasi secara luas, lengkap dan mudah dipahami mengenai ilmu pengetahuan atau khusus tentang cabang ilmu pengetahuan tertentu yang tersusun berdasarkan abjad atau kategori dan dicetak dalam bentuk buku (Ahira, 2011:1). Kriteria ini didasarkan pada hasil penilaian reviewer yaitu $87,42 \%$ yang berarti masuk dalam kategori Sangat Baik (SB) dan hasil yang diperoleh dari ujicoba secara terbatas pada mahasiswa dan siswa masing-masing sebesar $89,3 \%$ dan $84,8 \%$, termasuk dalam kategori Sangat Baik (SB). Sumber belajar yang baik idealnya memenuhi 4 kriteria yaitu kesesuaian (relevansi), kemudahan, kemenarikan, dan kemanfaatan. Berdasarkan hasil penelitian yang telah dilakukan, secara umum Ensiklopedi Mobile telah memenuhi kriteria tersebut sehingga Ensiklopedi Mobile yang telah dikembangkan bisa digunakan sebagai sumber belajar bagi siswa (Mulyanta dan Leong, 2009:3-4).

Penggunaan sumber belajar merupakan bagian yangintegral dari keseluruhan proses pembelajaran. Pembelajaran biologi dalam kurikulum 2013 memiliki harapan yang mengarah pada terwujudnya literasi sains diantaranya adalah agar siswa memiliki (a) kemampuan dalam berfikir kritis dan kreatif; (b) kemampuan berkomunikasi; (c) kemampuan dalam mempertimbangkan masalah dalam sisi moral; (d) memiliki minat luas dalam kehidupan dan kesiapan untuk bekerja; dan (e) peduli terhadap lingkungan. Salah satu cara yang bisa dilakukan untuk mewujudkan harapan dalam kurikulum 2013 adalah dengan melatih ketrampilan proses siswa dalam pembelajaran sains.

Keterampilan proses yang dimaksud ada lah:observation,classification,measurement, dan inference, communication, dan prediction (Collette \& Chiappetta, 1994:33-41).Oleh sebab itu, produk yang dikembangkan selain memuat konten materi pelajaran juga menambahkan menu yang bisa mengakomodir keterampilan proses dalam biologiberupa menu Identifikasi.Pengaplikasian Ensiklopedi Mobile dalam kegiatan pembelajaran di sekolah bisa melalui 3 cara yaitu Ensiklopedi Mobile digunakan sebagai tambahan (suplemen), pelengkap (komplemen) atau pengganti (subtitusi) dari sumber belajar lain yang sudah ada. Dengan mengaplikasikanya dalam kegiatan pembelajaran biologi diharapkan produk Ensiklopedi Mobile bisa memperlancar proses interaksi antara guru dengan siswa, dalam hal ini membantu siswa belajar secara optimal.
Ensiklopedi Mobile berbasis Android memiliki beberapa kelebihan. Pertama, ensiklopedi Mobile dijalankan menggunakan handphone sehingga siswa bisa belajar tanpa harus terikat waktu dan tempat. Kedua, materi dilengkapi dengan gambar yang representatif sehingga memudahkan siswa dalam memahami konsep. Ketiga, aplikasi Ensiklopedi Mobile memiliki tampilan background, header, icon dan panel yang menarik. Keempat, menu identifikasi memudahkan siswa mengelompokan spesies tumbuhan ke dalam kedudukan taksonominya. Kelima, aplikasi Ensiklopedi Mobile dilengkapi dengan forum diskusi untuk memfasilitasi siswa berinteraksi melalui jaringan internet. Keenam, aplikasi Ensiklopedi Mobile berjalan pada mode offline maupun online sehingga siswa tidak mutlak tergantung dengan ketersediaan jaringan internet saat mengakses materi.

Hal tersebut memberikan kesempatan yang luas bagi siswa untuk kreatif. Selaras dengan pendapat Davies (2000:11-12), pada era informasi yang luas dengan beragam perubahan yang dinamis, maka perlu ditingkatkan kualitas pendidikan untuk mencapai kompetensi yang maksimal. Selanjutnya, masyarakat ilmiah tidak hanya menghargai siswa yang memiliki kemampuan berpikir logis, berpikir kritis, kemampuan mencari solusi masalah, tetapi juga usaha yang kuat, inovasi yang orisinil dan kreatif. Oleh sebab itu, perlu dilatih cara berpikir kreatif dan sikap kreatif pada diri siswa.

Swan (2005:99-112) menjelaskan dalam penelitiannya, dibandingkan dengan penggunaan komputer desktop dalam pembelajaran, Ensiklopedi Mobile memungkinkan pengguna untuk menjalankan perangkat mobile computing sekaligus berinteraksi dengan sesama pengguna yang lain pada saat yang bersamaan. Ensiklopedi Mobile mendukung pembelajaran secara mandiri maupun secara kolaboratif. Selain itu Ensiklopedi Mobile juga mendukungpembelajaran di luar kelas formal kapanpun dan dimanapun sehingga mendukung terlaksananya proses belajar sepanjang hayat. Selain memiliki kelebihan, Ensiklopedi Mobile juga memiliki keterbatasan di antaranya adalah:1) kunci determinasi baru mencakup Divisi Pteridophyta, dan 2) menu forum diskusi belum mendukung pembuatan group-group yang memisahkan siswa dan guru dari sekolah berbeda. 


\section{SIMPULAN}

Simpulan yang dapat diambil pada penelitian pengembangan ini adalah sebagai berikut. Penelitian pengembangan telah menghasilkan Aplikasi Ensiklopedi Mobile berbasis Android untuk siswa Madrasah Aliyah dalam rangka implementasi Kurikulum 2013 dengan menggunakan model ADDIE. Tahapan yang dilalui adalah Analysis, Design, Develop, dan Evaluation sehingga diperoleh produk akhir Ensiklopedi Mobile berbasis Android. Ensiklopedi Mobile berbasis Android berdasarkan penilaian seluruh reviewer, peer reviewer, respon mahasiswa, dan siswa menunjukkan kualitas Sangat Baik. Hasil perolehan data menunjukkan bahwa Ensiklopedi Mobile berbasis Android layak digunakan sebagai sumber belajar Siswa kelas X Madrasah Aliyah dalam rangka implementasi Kurikulum 2013.

\section{UCAPAN TERIMA KASIH}

Peneliti Mengucapkan terima kasih kepada Direktorat Jenderal Pendidikan Tinggi Islam yang telah mendanai dan memfasilitasi publikasi ilmiah dalam bentuk HAKI. Semoga publikasi ilmiah ini dapat memberikan kontribusi khususnya dalam bidang pendidikan.

\section{DAFTAR PUSTAKA}

Ahira, Anne. 2011. Ensiklopedi. http://www.anneahira. Diakses tanggal 21 Februari 2015 pukul 10.34 WIB.

Collette, Alfred T. \& Chiappetta, Eugene L. 1994. Science Instruction in The Middle and Secondary Schools. New York: Macmillan Publishing Company.

Davies, T. 2000. Confidence! Its Role in the Creative Teaching and Learning of Design and Technology. Journal of Technology Education. Hlm 12. Diambil pada tanggal 30 oktober 2008, darihttp://scholar.lib.vt.edu/ ejournals/JTE/v12n1/davies.html

Gandhewar, Nisarg dan Sheikh,Rahila. 2010. "Google Android: An Emerging Software Platform For Mobile Devices." International Journal on Computer Science and Engineering (IJCSE).ISSN 0975-3397. hlm.1-17.
Katuuk, Deitje Adolfien. 2014. "Manajemen Implementasi Kurikulum: Strategi Penguatan Implementasi Kurikulum 2013." Dalam Cakrawala Pendidikan, Jurnal Ilmiah Pendidikan, XXXIII (1), hlm. 13-26.

Mulyanta, St dan Leong, Marlon. 2009. Tutorial Membangun Multimedia Interaktif Media Pembelajaran. Yogyakarta: Universitas Atma Jaya.

Nilakusmawati, Desak Putu Eka. 2010. "Kajian Pengetahuan Guru mengenai Internet sebagai Salah Satu Sumber Referensi dalam Penyusunan Karya Tulis Ilmiah". Dalam Cakrawala Pendidikan, Jurnal Ilmiah Pendidikan, XXIX (2), hlm. 147 - 160.

Padmo, Dewi dan Purwanto, dkk. 2004. Peningkatan Kualitas Belajar melalui Teknologi Pembelajaran. Jakarta: Pusat Teknologi Komunikasi dan Informasi Pendidikan.

Quesinberry, Neal. 2011. 7 Tips for Designing Effective Mobile Learning. Diakses dari learningsolutions.jplcreative.com. 15 November 2013.

Riyanto, Bambang dan Tamimuddin,Muh., dkk. 2006. Perancangan Aplikasi M-Learning Berbasis Java. Prosiding Konferensi Nasional Teknologi Informasi \& Komunikasi untuk Indonesia. Bandung: Institut Teknologi Bandung

Rizki dan Ranius, A. Yani, dkk. 2014. "Implementasi Metode Mobile-D untuk Pembuatan Ensiklopedia Kebudayaan Kota Palembang Berbasis Android." Dalam Cakrawala Pendidikan, Jurnal Ilmiah Pendidikan, XXXIII (1), hlm. 1-12.

Shihab, M. Quraish. 2011. Tafsir Al-Mishbah: Pesan, Kesan dan Keserasian al-Qur'an. Jakarta: Lentera Hati

Subali, Bambang dan Mariyam, Siti. 2013. "Pengembangan Kreativitas Keterampilan Proses Sains dalam Aspek Kehidupan Organisme pada Mata Pelajaran IPA SD". Dalam Cakrawala Pendidikan, Jurnal Ilmiah Pendidikan, XXXII (3), hlm. 365 - 381. 
Sudjana, Nana. 2010. Penilaian Hasil dan Proses Belajar Mengajar. Bandung: Remaja Rosdakarya.

Sugiyono. 2011. Metode Penelitian Pendidikan (Pendekatan Kuantitatif, Kualitatif, dan $R$ $\& D)$. Bandung: Alfabeta.

Surjono, Herman Dwi dan Gafur, Abdul. 2010. "Potensi Pemanfaatan ICT untuk Peningkatan Mutu Pembelajaran SMA di Kota Yogyakarta”. Dalam Cakrawala Pendidikan, Jurnal Ilmiah Pendidikan, XXIV (2), hlm. $161-175$.

Swan, Karen. 2005. "Uses and Effects of Mobile Computing Devices in $\mathrm{K}-8$
Classrooms."Journal of Research on Technology in Education. (Online) Diakses dari www.iste.org. 16 November 2014. Volume 38 No 1 , hlm $99-112$.

Syah, M. 2005. Psikologi Belajar. Jakarta: PT Raja Grafindo Persada.

Warsita, Bambang. 2008. Teknologi Pembelajaran. Jakarta: Rineka Cipta.

Wijaya, Stevanus Wisnu. 2006. Mobile Learning sebagai Model Pembelajaran Alternatif bagi Pemulihan Pendidikan di Daerah Bencana Alam Gempa Bumi Yogyakarta. Yogyakarta:Universitas Sanata Dharma. 